\title{
Special Issue: Global Perspectives on Business Ethics from the 40th Anniversary Conference of the Hoffman Center for Business Ethics at Bentley University, 2016
}

\author{
Virginia W. Gerde ${ }^{1} \cdot$ Christopher Michaelson $^{2}$
}

Received: 4 April 2018 / Accepted: 28 May 2018 / Published online: 14 May 2018

○) Springer Science+Business Media B.V., part of Springer Nature 2018

\begin{abstract}
This special issue of the Journal of Business Ethics (JBE) commemorates the 40th Anniversary Conference of the Hoffman Center for Business Ethics at Bentley University. It collects seven of the papers that were presented at the conference in 2016, when scholars, practitioners, and policymakers from across the globe convened to discuss "Global Perspectives on Business Ethics." From conceptual thinking to theory building and empirical analysis, these articles present several future and mutually supportive directions for research to influence the context and conduct of business through its challenges and changes over the next 40 years.
\end{abstract}

Keywords Global business ethics · Corporate governance $\cdot$ Corporate social responsibility

This special issue of the Journal of Business Ethics (JBE) commemorates the 40th Anniversary Conference of the Hoffman Center for Business Ethics at Bentley University. It collects seven of the papers that were presented at the conference in 2016, when scholars, practitioners, and policymakers from across the globe convened to discuss "Global Perspectives on Business Ethics." While the papers collected here were written by scholars and have gone through peer review since they were originally presented, they each allude to the broader context of the conference-and the Center's history-that is firmly rooted in the practical conduct of business. That context and conduct are about challenges to and changes in global business ethics: what challenges and changes have happened, how to enable change that has yet to occur, and what those changes should or challenges could be. The scholars are respectful of past research and practice, but they remind business researchers and practitioners that there is more to accomplish for scholarship and society.

Christopher Michaelson

cmmichaelson@stthomas.edu

Virginia W. Gerde

virginia.gerde@furman.edu

1 Furman University, Greenville, SC 29613, USA

2 University of St. Thomas, St Paul, MN 55105, USA
At the 2016 conference, the Center was renamed the Hoffman Center for Business Ethics (HCBE) after its founder, W. Michael Hoffman, a professor and pioneer in the field. The Center has worked for and witnessed how the field of business ethics has grown and progressed in practice, theory, and methodology in its 40 years. The fact that many businesses have formalized ethics and compliance programs in that time can be traced in significant part to the founding of the Ethics Officer Association (EOA) at Bentley in 1992, with Hoffman as its first executive director. The EOA, which became the Ethics and Compliance Officer Association and is now part of the Ethics and Compliance Initiative, remains one of the first and most influential professional associations in the field. Similar to some of the business ethics practitioners who spoke at the conference and confessed to learning by doing, Hoffman admitted that when he sought the university president's permission to create the Center, he did not yet know what it would do. Hoffman also had a hand in founding the Society for Business Ethics, a leading and international academic association. Over time, the Center has hosted some of the most important scholars in the field, sharing their research and collaborating with practitioners, the public, and students. It also became an innovation lab for teaching business ethics both in classrooms and in boardrooms. An early adopter of technology, the Center enabled team-teaching across continents. As ethics and compliance management has advanced in practice, business ethics has 
become a standard part of academic curricula, and policy and public awareness of the role of business in society have advanced.

Celebrating the fifth decade of the Hoffman Center for Business Ethics at Bentley University, which nearly coincides with $J B E$ 's fifth decade ahead, this special issue highlights the diversity of approaches, methods, and disciplines advancing the practice of business ethics.

The seven papers in this special issue represent a variety of methodological and disciplinary areas brought to bear on several levels of analysis, from individual virtue to boardroom governance. If a business executive or professor asked, "What are the current developments and issues in business ethics today?" this special issue would provide a glimpse into the breadth of the field, the complexity of the issues it examines, and the anticipated challenges it faces. They would see that business ethics is more complicated than doing the right thing. It requires public-private partnerships, market regulation, effective organizational governance, managerial coordination, and-perhaps most evident in this collection of papers-individual virtue influencing organizations and institutions.

In the articles that follow, these authors eschew hubris and take a candid look at the business ethics field, its faults, and how it should or could develop. As Brenkert writes: “... we should also take some time to see not only the importance and successes of business ethics, but also the challenges and limits of global business ethics" (2018). In doing so, the authors utilize a range of levels of analysis, from the systems level (Brenkert 2018; Waddock 2018), the institutional level expressed as international business (Bowie 2018) and finance (Sison et al.), the organizational level (PainterMorland et al. 2018; Steckler and Clark 2018), and the individual level of moral competency (Sanz and Fontrodona 2018).

\section{Mind the Gap! The Challenges and Limits of (Global) Business Ethics}

While acknowledging the progress in business ethics and in business ethics pedagogy at the individual level, Brenkert (2018) draws our attention to the gap between "the Evaluative, Embodiment, and Enforcement aspects of business ethics" and an "Enactment theory"-a theory of moral change. In effect, there is a gap between "what businesses should be doing and what they actually do," or in other words the "how" of improving global business ethics and behavior. Using a metaphor with the London Underground's "Mind the Gap" awareness campaign, Brenkert likens the successes of business ethics to developing awareness but not necessarily working to close the gap itself. Reducing the size of the gap, he contends, will involve transformative institutional change involving elements of Gaventa's (2006) work on the role of power in change and resistance to change. In understanding change and theorizing how to enact change, Brenkert also calls for business ethicists to identify unethical forms of influence as well as cultural and political barriers to making such changes.

\section{Shaping the Shift: Shamanic Leadership, Memes, and Transformation}

How do we accomplish change, especially involving the whole of human systems? In "Shaping the shift: Shamanic leadership, memes, and transformation," Waddock (2018) develops the concept of shamanic leaders who can help shape a societal shift toward a more sustainable world by exercising the three roles of a traditional shaman: a healer, a connector, and a sensemaker. Business leaders can and should adopt "the mantle of the shaman" to effect change by being able to step out of their current mindsets, envision a new future and how to get there, and then communicate with others to enable the start of that new future to take root. She explores the role of memes in sensemaking at multiple levels, with the shamanic leader shifting these memes to portray a different narrative. For example, the meme of growth is a building block for our current view of businesses as pursuers and engines of growth, but the meme of sustainability can enter the "story" and shift our eventual understanding of the goals and measures of success for businesses.

\section{International Business as a Possible Civilizing Force in a Cosmopolitan World}

Seeing the possibility of a market economy as a moralizing agent (Doux-Commerce Thesis, Hirschman 1982), Bowie presents "International business as a possible civilizing force in a cosmopolitan world" (2018). The author admits optimism and maintains that there has been a general movement by multinational corporations (MNCs) to more civilizing actions from their own actions and the exercise of political and economic influence. He illustrates his optimism with positive examples of multilateral collaboration for positive social and environmental change, including the Ruggie Principles (2011), the UN Sustainable Development Goals, and the UN Global Compact. Bowie recognizes that business also has a checkered past and provides examples of when business has been a destructive force. Yet scholars, teachers, and business leaders will likely find these current examples from multiple industries useful to explain the potential for business to fulfill his optimistic vision in the dynamic and diverse business environments of the twentieth first century. 
From minding (and then closing) the gap (Brenkert 2018) to the leadership needed at the individual level (Waddock 2018) and firm level (Bowie 2018), the three previous articles call for change to stimulate global business ethics. The next four articles look more specifically at the governance, leadership, professional, and personal competencies needed within a firm.

\section{Authenticity and Corporate Governance}

Boards of directors may be the ethical guardians of shareholders' and potentially even stakeholders' investments in the firm, but Steckler and Clark (2018) observe that "scholarship has largely overlooked the value and implications of individual virtue in governance practice". Much research on ethics and governance, they claim, has focused on the structure and process of governance as well as on the knowledge and experience of directors. Yet such research has said comparatively little about the moral wisdom of those same people. Steckler and Clark focus their analysis on authenticity as a common sense virtue that is a quality of individuals but that can also influence the collective dynamics of a body of decision-makers. They present the board of directors as a collection of human moral agents that in the discourse and practice of corporate governance is often considered in the abstract, even while its decisions and actions affect other human moral agents.

\section{Sharing Vocabularies: Towards Horizontal Alignment of Values-Driven Business Functions}

While it makes sense that corporate social responsibility (CSR) and ethics and compliance (E\&C) would be philosophically aligned, scholarship and practice in these areas is often conceptually and operationally siloed. With a historical perspective on the development of these disciplines, Painter-Morland et al. (2018) show the synergies of the two movements and how each can contribute to a values-driven business. In "Shared vocabularies and practices towards values-driven business: Bridging the divide between ethics and compliance and corporate social responsibility (CSR) functions," the authors' purpose is to learn from the past and current manifestations of CSR and E\&C in order to develop a more integrated commitment to values and a more cohesive approach to ethics in management. Similar to Brenkert's "gap," Painter-Morland and colleagues identify a "divide" between theory and practice that their framework seeks to bridge.

\section{Moderation as a Moral Competence: Integrating Perspectives for a Better Understanding of Temperance in the Workplace}

Temperance is another moral virtue that may be undervalued in business practice. In "Moderation as a moral competence: Integrating perspectives for a better understanding of temperance in the workplace," Sanz and Fontrodona (2018) provide several examples of business ethics failures in which a deficiency of temperance was partially to blame. Taking an interdisciplinary approach, they define temperance rooted in moral philosophy as "the moral virtue that introduces certain order or moderation to the sensible appetites that appear stronger and more attractive to human beings" and seek to articulate character strengths of temperance as depicted in positive psychology. By presenting temperance as a moral competency in a professional context, the authors identify several business contexts in which temperance is needed: (1) consumption of appealing substances, (2) emotional relationships among individuals, (3) use of money and other monetary or natural resources, (4) management of time and amusement, and (5) management of knowledge and information (2018).

\section{Characterizing Virtues in Finance}

Of course, many of the business ethics failures in recent memory can be attributed to "financialization," or the vice in which "moral agents are overcome by inordinate desire for wealth or greed". In their paper, "Characterizing Virtues in Finance," Sison et al. (2018) build on their past work on the vice of financialization to outline how virtues also may be enabled in the field and practice of finance. Drawing on Aristotle, Catholic social thought, and MacIntyrean virtue ethics that are often seen to be hostile to the accumulation of wealth, the authors acknowledge some necessary and arguably valuable functions that finance plays in the conduct of the good life in modern society, from cultivating household savings to facilitating payment and trade among goods and services. They go so far as to say that, in proper balance, "ethics and economy constitute the two pillars on which politics, the body of knowledge regulating the good life in society, rests". 


\section{Conclusion}

Ultimately, business ethics is about the interaction of ethics and economy for the good life in society. As the W. Michael Hoffman Center for Business Ethics enters its fifth decade, it continues its mission of giving "leadership in the creation of organizational cultures that align effective business performance with ethical business conduct ... [through] expertise, research, education and a collaborative approach to disseminating best practices" (HCBE 2018). From the smallest of transformational memes (Waddock 2018) to the largest of multinational corporations as change agents (Bowie 2018), the authors of these papers commemorating the Hoffman Center for Business Ethics' important milestone examine the interconnectedness of the individual, groups, and the larger ecosystems. They encourage us to consider on economic, management, political, and societal theories to inform our business ethics scholarship and "close the gap" from "the right thing to do" to "doing the right thing." From conceptual thinking to theory building and empirical analysis, these articles present several future and mutually supportive directions for research to influence the context and conduct of business through its challenges and changes over the next 40 years.

Acknowledgements We are thankful for the authors' contributions and for their receptiveness to the valuable feedback from many reviewers for whose efforts we are also grateful. We are also honored to have been selected to guest edit this special issue and so thank this journal's editors and the Hoffman Center for that distinction.

\section{Compliance with Ethical Standards}

Conflict of interest The authors declare that they have no conflicts of interest.

Ethical Approval This article does not contain any studies with human participants or animals performed by any of the authors.

\section{References}

Bowie, N. (2018). International business as a possible civilizing force in a cosmopolitan world. Journal of Business Ethics. https://doi. org/10.1007/s10551-017-3670-8.

Brenkert, G. (2018). Mind the gap! The challenges and limits of (Global) business ethics. Journal of Business Ethics. https://doi. org/10.1007/s10551-018-3902-6.

Gaventa, J. (2006). Finding the spaces for change: A power analysis. IDS Bulletin, 37(6), 23-33.

HCBE. (2018). https://www.bentley.edu/centers/center-for-businessethics.

Hirschman, A. O. (1982). Rival interpretations of market society: Civilizing, destructive, or feeble? Journal of Economic Literature, 20, 1463-1484.

Painter-Morland, M., Pouryousefi, S., Hibbert, S., \& Russon, J.-A. (2018). Sharing vocabularies: Towards horizontal alignment of values-driven business functions. Journal of Business Ethics. https ://doi.org/10.1007/s10551-018-3901-7.

Ruggie, J. (2011). Report of the special representative of the secretarygeneral on the issue of human rights and transnational corporations and other business enterprises: Guiding principles on business and human rights: implementing the united nations 'protect, respect and remedy' framework. Netherlands Quarterly of Human Rights, 29(2), 224-253.

Sanz, P., \& Fontrodona, J. (2018). Moderation as a moral competence: Integrating perspectives for a better understanding of temperance in the workplace. Journal of Business Ethics. https://doi. org/10.1007/s10551-018-3899-x.

Sison, A., Ferrero, I., \& Guitián, G. (2018). Characterizing virtues in finance. Journal of Business Ethics. https://doi.org/10.1007/ s10551-017-3596-1.

Steckler, E., \& Clark, C. (2018). Authenticity and corporate governance. Journal of Business Ethics. https://doi.org/10.1007/s1055 1-018-3903-5.

Waddock, S. (2018). Shaping the shift: Shamanic leadership, memes, and transformation. Journal of Business Ethics. https://doi. org/10.1007/s10551-018-3900-8. 